\title{
EFFICACY OF THE NATIONAL PROGRAM OF IRON SUPPLEMENTATION IN THE ANAEMIA CONTROL IN INFANTS ASSISTED BY CHILD EDUCATION CENTERS
}

\author{
Tamara Eugenia Stulbach ${ }^{1}$, Jose João Name ${ }^{2}$, Blanca Elena Guerrero Daboin ${ }^{3}$, \\ Sophia Cornbluth Szarfarc ${ }^{4}$
}

\begin{abstract}
Introduction: iron deficiency occurs in endemic proportion among children and is one of the causal factors of inappropriate cognitive, social, motor and reduced learning ability, putting infants as a priority group for nutritional intervention programs aiming to control iron deficiency. Thus, in 2005 the Ministry of Health established the National Program of Iron Supplementation (PNSF) available for the universe of children of 6-24 months old attended in Basic Health Units.Objective: to estimate the prevalence of anaemia and analyse the efficacy of profilatic supplementation with ferrous sufate. Methods: a prospective follow-up study intervention that was developed in the city of Guarujá - SP, Brazil in the universe of children between 6-24 months old attended in the Public Basic Health Units whose parents authorized their participation. The supplement was offered in accordance with the standards of PNSF and diagnosis of anaemia was performed before and 6 months after the intervention period. As a criterion for anaemia was used the standards of the World Health Organization that defines moderate anaemia to haemoglobin $(\mathrm{Hb})$ between 11.0 and 9,5g Hb/dL and severe anaemia to below $9,5 \mathrm{gHb} / \mathrm{dL}$. Results: a total of 136 children under two years, ( $81 \%$ of total) participated in the study. No statistically significant difference was found between the mean Hb concentration before and after the intervention period $(p=0.684)$. The initial mean $\mathrm{Hb}$ was $11,6 \mathrm{~g} / \mathrm{dL}(\mathrm{SD}=1.82)$ and the final $11.5 \mathrm{~g} / \mathrm{dL}(S D=1.31)$. Although only 11 of the 49 anemic reached normal values, 33 of them showed an increase in $\mathrm{Hb}$ concentration.Conclusion: there was an increase in $\mathrm{Hb}$ concentration among children with severe anaemia. There was no change in the situation of children with moderate anaemia. Supplementation with ferrous sulphate was not sufficiently effective in controlling iron deficiency in infants .
\end{abstract}

Key words: Iron deficiency anaemia, infants, supplementation with iron , ferrous sulphate, National Program of Iron Supplementation (PNSF).

\section{INTRODUCTION}

Anaemia is seen as one of the causes of inadequate cognitive, social, motor development as well as decreasethe learning ability in children. This is the reason why infants are a priority group of the nutritional program of iron deficiency control ${ }^{1}$. The national commitment to reduce the prevalence of anaemia in pregnant women in one third until 2000 and deferred to 2003 was legitimately extended to preschool children.

Taking into account the fact that children up to 2 years old benefit very little from iron-fortified diets and infants great vulnerability to martial deficiency, in May 2005, based on chinese intervention studies ${ }^{2}$, the Ministry of Health instituted the National Program of Iron Supplementation for children from 6 to 24 months oldconsisting of a weekly supplementation with ferrous sulphate ${ }^{3}$.

In support of the drug supplementation with prophylactic doses of iron, there was the idea established for decades, that the supplementation is the fastest and the most inexpensive and effective way to control specific nutritional deficiencies. The weekly prophylactic supplementation with ferrous sulphate that had showed excellent results among children with anaemia in China $^{2}$ proved to be effective when it was used in the eradication program of iron deficiency anaemia in the district

1 Doutora em Nutrição Saúde Pública pela FSP/USP, nutricionista da Secretaria Municipal de Saúde da Prefeitura Municipal de Guarujá, SP.

2 Medical doctor MD, Master and PhD student in Social Sciences, Kilyos Assessoria Consultoria C.P. Ltda

3 Laboratório de Delineamento de Estudos e Escrita Científica da Faculdade de Medicina do ABC. Departamento de Saúde da Coletividade. Santo André, SP.

4 Professora Associada. Departamento de Nutrição, Faciuldade de Saúde Pública da Universidade de São Paulo.

Trabalho baseado na Tese "Avaliação do Programa Nacional de Suplementação de Ferro no controle de anemia, em crianças de 6 a 24 meses, assistidas nos Centros de Educação Infantil do município do Guarujá", de Tamara Eugenia Stulbach, orientada por Sophia Cornbluth Szarfarc, programa de Pós Graduação em Saúde Pública, USP, 2009.

Application in Field Public Health: the implementation of the National Program of Iron Supplementation does not present a perspective of effectiveness as a solution for the control of iron deficiency in unfants.

Corresponding author: scfarc@usp.br

Suggested citation: Stulbach TE, et al. Efficacy of the National Program of Iron Supplementation in the anemia control in infants assisted by Child Education Centers. 24(3): 282-288

Manuscript submitted Jun 20 2014, accepted for publication Oct 282014. 
of São Paulo4. Since it avoided the reduction of haemoglobin and stabilized the levels of this indicator, the proposal was a viable alternative to control the deficiency.

Preceding the introduction of the National Program of Iron Supplementation throughout Brazil in May 2005, In 1998, the São Paulo model was adopted as a strategy by the "Project to control the iron deficiency anaemia in infants under 2 years old" in 512 Northeastern districts included in the Program of Child Mortality Reduction ${ }^{5}$.

Thus, the objective is to estimate the prevalence of anaemia and analyse the efficacy of profilaticsupplementation with ferrous sulphate.

\section{METHODS}

It is a prospective follow-up intervention study. It was done in the district of Guarujá - SP and the subject of this study are infants from 6 to 24 months old enrolled in the Centers of Child Education of the district whose parents/responsible authorized their participation.

The study was approved by the Research Ethics Committee of the Public Health School of the University of São Paulo - COEP/FSP - in compliance with the requirements of Resolution CNS/196/96 and supported by the Board of Education of Guarujá.

The iron supplementation followed the guidelines of the National Program of Iron Supplementation $^{3}$ (Department of Health, 2005). The bottles of ferrous sulphate were supplied by the Ministry of Health and were to offer every week
$25 \mathrm{mg}$ of iron ( $5 \mathrm{ml}$ of syrup) to the infants who were participating.

The assessment of haemoglobin [Hb] concentration for the anaemia diagnosis was carried out at the beginning of the supplementation and after the period of the 24-weeks intervention.

For the anaemia diagnosis was used World Health Organization ${ }^{6}$ guideline which defines moderate anaemia when $\mathrm{Hb}$ values are between $11,0 \mathrm{~g} / \mathrm{dL}$ and $9,5 \mathrm{~g} / \mathrm{dL}$ and severe anaemia for values equal to $9,5 / \mathrm{dL}$ or below.

For data analysis the STATA 14.0 statistic program was used. Averages, standard deviations and proportions were evaluated. The resulting impact of the intervention was evaluated by Student's parametric t-test and the possible association by McNemar's Chi-square test of discordant pairs. In all statistic tests, the significance level adopted was equal to $5 \%$.

\section{RESULTS}

Iron deficiency is seen as one of the causes of inadequate cognitive, social, motor development as well as decreasethe learning ability in children. This is the reason why infants are a priority group of nutritional intervention programs to control iron deficiency.

The results showed through the tables 1 to 4 and figure 1 present an analysis of the National Program of Iron supplementation (PNSF) implanted by the Health Ministry of Brazil, this program is available for the universe of children between 6 and 24 months of age attended in primary healthcare units.

Table 1: Distribution of infants according to anaemia prevalence before and after the ingestion of iron supplement.Guarujá, São Paulo, Brazil - 2007

$\begin{array}{ccc}{[\mathbf{H b}] \mathbf{g} / \mathbf{d L}} & \text { Before supplementation \% }\left(\mathbf{n}^{\mathbf{0}}\right) & \text { After supplementation } \%\left(\mathbf{n}^{\mathbf{0}}\right) \\ >11.0 & 63.9(87) & 72.0(98) \\ >9.5<11.0 & 22.1(30) & 22.1(30) \\ <9.5 & 14.0(19) & 5.9(8) \\ \text { Total } & 100(136) & 100(136)\end{array}$

Table 2: McNemar paired association of haemoglobin concentration before and after intervention. Guarujá, São Paulo, Brazil, 2007

\begin{tabular}{|c|c|c|c|}
\hline Anaemia & $\begin{array}{l}\text { Before with } \\
\mathrm{Hb}<11.0 \mathrm{~g} / \mathrm{dL}\end{array}$ & $\begin{array}{l}\text { Before without } \\
\mathrm{Hb}<11.0 \mathrm{~g} / \mathrm{dL}\end{array}$ & $\%$ \\
\hline $\begin{array}{c}\text { After with } \\
\mathrm{Hb}<11.0 \mathrm{~g} / \mathrm{dL}\end{array}$ & 23 & 15 & 27.9 \\
\hline $\begin{array}{l}\text { After without } \\
\mathrm{Hb}<11.0 \mathrm{mg} / \mathrm{dL}\end{array}$ & 26 & 72 & 72.1 \\
\hline$\%$ & 36.0 & 64.0 & \\
\hline
\end{tabular}

$\chi^{2}=2.439 \quad 1$ g.l. $p=0.1183$ n.s. 


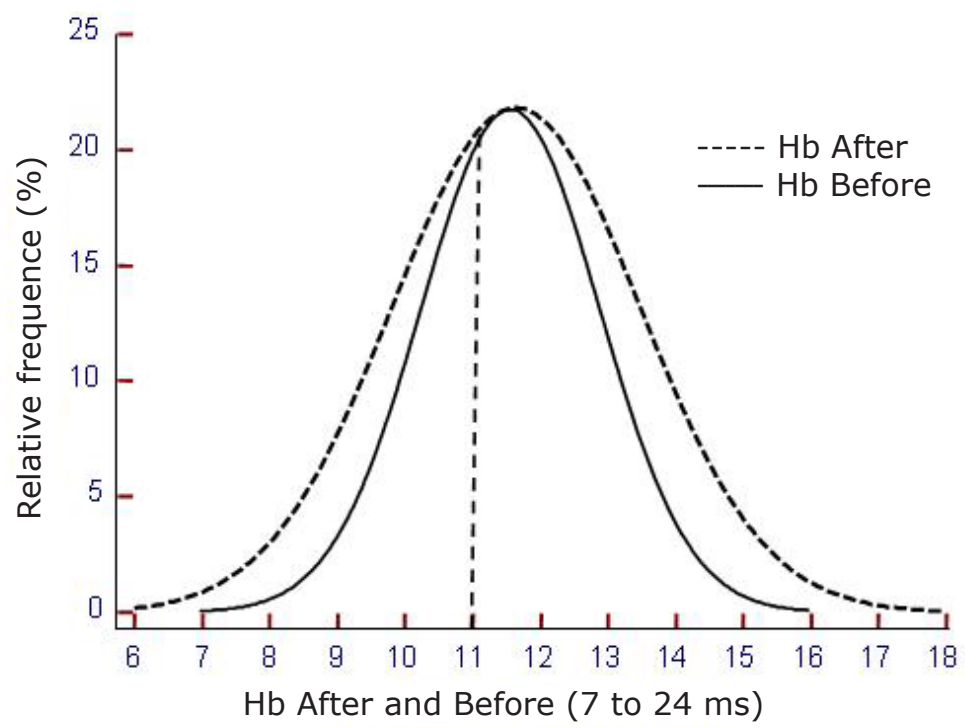

Figure 1: Relative frequency of haemoglobin concentration before and after supplementation with ferrous sulfate during 6 months. Guarujá, 2007.

Table 3: Paired $\mathrm{t}$ - tests for [Hb] before and after iron supplementation according to age. Guarujá, 2007

\begin{tabular}{|c|c|c|c|c|c|}
\hline $\begin{array}{c}\text { Age } \\
\text { Months }\end{array}$ & No & Hb before intervention & $\mathrm{Hb}$ after intervention & Paired t-test & $\mathbf{P}$ \\
\hline $07-12$ & 24 & $11.61(1.91)<11.0=9$ & $10.94(1.46)<11.0=10$ & $\mathrm{~T}$ paired $=2.0723 \mathrm{~g} . \mathrm{I}$ & $0.05^{*}$ \\
\hline $13-18$ & 58 & $11.75(2.12)<11.0=22$ & $11.63(1.11)<11.0=15$ & $\mathrm{~T}$ paired $=0.4557 \mathrm{~g} . \mathrm{l}$ & 0.65 \\
\hline $19-24$ & 54 & $11.53(1.45)<11.0=18$ & $11.81(1.37)<11.0=13$ & $\mathrm{~T}$ paired $=1.7353 \mathrm{~g} . \mathrm{I}$ & 0.09 \\
\hline Total & 136 & $11.64(1.83)<11.0=49$ & $11.58(1.31)<11.0=38$ & $\mathrm{~T}$ paired $=0.41135 \mathrm{~g} . \mathrm{l}$. & 0.68 \\
\hline
\end{tabular}

* significant difference.

Table 4: Unpaired t-test groups comparing same age infants with or without iron supplement. Guarujá, SP, 2014.

\begin{tabular}{|c|c|c|c|c|c|}
\hline $\begin{array}{c}\text { Age } \\
\text { (months) }\end{array}$ & $\begin{array}{l}N^{\circ} \text { of } \\
\text { infants }\end{array}$ & $\begin{array}{l}\mathrm{X} ; \text { d.p. }[\mathrm{Hb}] \text { nonfortified } \\
\text { group } \%<11,0 \mathrm{~g} / \mathrm{dL}\end{array}$ & $\begin{array}{l}X ; \text { d.p. [Hb] fortified } \\
\text { group } \mathrm{N}<11,0 \mathrm{~g} / \mathrm{dL}\end{array}$ & Unpaired t-test & $\mathbf{P}$ \\
\hline $13-18$ & $B=58 A=24$ & $B=11.75 ; 2.12 \%=38$ & $A=10.94(1.46) \%=41$ & Unpaired $\mathrm{T}=2.00$ & $0.05^{*}$ \\
\hline $19-24$ & $B=54 A=58$ & $B=11.53(1.45) \%=33$ & $A=11.63(1.11) \%=26$ & Unpaired $\mathrm{T}=0.42$ 99g.l. & 0.67 \\
\hline
\end{tabular}

B - Initial values before intervention;

A - values found after 24 weeks of iron supplement.

* Significant difference

\section{DISCUSSION}

Iron deficiency is seen as one of the causes of inadequate cognitive, social, motor development as well as decreasethe learning ability in children. This is the reason why infants are a priority group of nutritional intervention programs to control iron deficiency.

Despite the reduction observed in infants with $[\mathrm{Hb}]<11.0 \mathrm{~g} / \mathrm{dL}$, among those with severe anaemia, $[\mathrm{Hb}]<9.5 \mathrm{~g} / \mathrm{dL}$, the population studied maintain thelevel of haemoglobin within the status classified as moderate risk according to $\mathrm{WHO}^{\prime} \mathrm{s}$ criteria ${ }^{6}$. There was no significant difference between $\mathrm{Hb}$ average concentration before and after the intervention $(p=0.684)$. The initial average of haemoglobin concentration in all infants $(n=136)$ was $11.6 \mathrm{~g} / \mathrm{dL}(\mathrm{DP}=1.82)$ and after intervention was $11.5 \mathrm{~g} / \mathrm{dL}(\mathrm{DP}=1.31)$.

Among infants who were initially anaemic, the difference between the averages of haemoglobin concentration before was $9.7 \mathrm{~g} / \mathrm{dL}$ and after the intervention $10.9 \mathrm{~g} / \mathrm{dL}$, a significant statistic difference. Although only 11 of 49 anemic infants get the normal level, 33 of then showed an increase in the haemoglobin concentration.

The McNemar's discordant pairs test of paired proportions (Table 2) shows that the presence of discordant pairs was random. Therefore, apparently the intervention didn't result in the expected positive 
impact resulting from a prophylactic supplementation.

According to Figure 1, there was a decrease in the haemoglobin values dispersion around the average and this difference (Test F) was significant, that is, there was a significant statistic decrease in the range of variation of the values observed in the two periods: before and after the intervention with iron supplementation in prophylactic doses.

Table 3 summarises the paired t-tests used to verify the differences among the children, before and after the intervention and shows a significant decrease in the average $\mathrm{HB}$ concentration when the group from 7 to 12 months is compared to itself, and the moment in which the group is already from 13 to 18 months old showing the influence of age in the anaemia determination.

The age influence in determining the haemoglobin concentration was evaluated by t-test, for same age groups, unpaired, having ingested the martial supplement or not (Table 4 ). Table 4 compares same age infants who ingested (A) iron supplement or not (B) stresses the importance of the physiological evolution model of haemoglobin concentration during the period which evidently shows that from 13 to 18 months the infant is more vulnerable to anaemia ${ }^{7}$

Iron deficiency anaemia is a huge epidemiologic problem as evidenced of the resources spent by the public health sector, the social consequences of rising pregnancy risk, the decrease in production, and also on long term consequences of mental development $1,8,9$

The results of controlling iron deficiency apparently are very simply: the increase of the mineral in the population diet will result in changes in the epidemiological data. Nevertheless the classic model of intervention highlights operational problems that prevent the emergence of the expected effect. The effectiveness of supplementation programs goes against a number of relevant political, administrative, economic, planning and management, organizational, material and human factors involving ultimately interests, motivation and beliefs.

We also have to consider, that FeSO4 in general chosen as supplement by its low cost and bioavailability causes undesirable side effects such as nausea, abdominal cramps, constipation and diarrhoea. Also the characteristic metallic taste (as present in most inorganic iron compounds), causes their rejection in daily ingestion 9,10 .

The control of iron deficiency in infancy, whose high prevalence has been reported frequently in national studies ${ }^{9-17}$, present additional problems: the FeSO 4 must be offered between the meals in order to prevent reduction of it potential absorption. A study of intervention where FeSO 4 was guidance for daily consumption shows after a period of six months a negligible adherence and a missing of $55 \%$ of the sample population resulting from both lack of interest and the awful flavor of the supplement ${ }^{12}$

Haemoglobin concentration values found among institutionalized infants from 6 to 23 months old, after a 6-month period of iron supplementation given by a government policy Intervention, emphasizes, once more, that an appropriate nutrition during the lactation period is the greatest determinant for the development and growth of children, mainly during their first two years of life 18-26. $^{18}$. At same time also remarks the iron dietary deficiency is the infants' anaemia greatest determinant among the children population (table 1 ).

Even though, the outcome among children with severe anaemia was positive, still the overall outcome is far from the eradication of anaemia. As it was expected, the greater the mineral depletion, the faster and more effective the response to a martial supplement is. Even so, the absence of association between before and after results (table 2) underlines the low efficacy of the intervention.

Figure 1 contains two curves with normal distribution that shows an interesting aspect of the result. The decrease of the variation range causes a lower percentage of infants with $[\mathrm{Hb}]$ below the average and in this case below $11,0 \mathrm{~g} / \mathrm{dL}$ where the two curves cross. The population with aboveaverage shows evidently a decrease of the variability of results, a fact that might be explained by the tendency of regression to the average. In view of the anaemia prevalence decrease as well as that of extreme values, it is legitimate to maintain the average concentration of haemoglobin in the population studied before and after the intervention.

The influence of age was observed in table 3 among paired children and in table 4 among unpaired ones. The evolution of haemoglobin concentration in the two first years of life shows a decrease of the indicator of anaemia from 18 months and after that, a slow increase. That model was observed in our population and can explain the results obtained in the comparison of 06-11 months before and after fortification (table 3 ) and among children with 13-18 months with and without fortification (table 4). In both cases, the absence of the expected positive effect of the intervention seems to be clear, but the effect of the age in the evolution of $[\mathrm{Hb}]$ is not.

Having moderate anaemia prevalence (Table 1) before and after the intervention decreased the positive expectation of anaemia control, whether it was severe or not. First, there is a hypothesis which may explain the result: the 6-month of supplement was insufficient to meet the need of iron and store it. From this hypothesis result two problems: although programs of prophylactic drug supplementation are the most traditional and inexpensive means of preventing iron deficiency.Such programs are limited by a series of political, organizational, management and administrative factors, and the participation of mothers or the responsibles for infants in the program for a long period also depends on the way health professionals guide their patients to use the substrate. Although there is a motivation, the effective use of iron supplement decreases as time goes by, especially because iron deficiency shows no signs and/or symptoms justifying the use of a "drug".

The PNSF was implemented in view of the economic advantages and the fast response from 
dietary supplements, as they are seen as medicines, and related to an illness without signs and/or symptoms.

Finding alternative interventions for the iron deficiency control may be based upon communitarian or domestic fortifications, adapted to each group of people ${ }^{27}$ The use of iron fortification of high absorption potential would significantly increase the possibilities of iron deficiency control with a low cost.

The result obtained in this study in addition to hypotheses justifying it, emphasizes the need of creating new options for the iron deficiency control. Considering the difficulty in terms of planning, carrying out and evaluating the National Program of Iron Supplementation in the community, it is interesting to think about the need of promoting intra- and inter-sectorial practices aimed at implementing national policies as already mentioned by the Policy of Health Promotion ${ }^{28}$.

Apparently, the use of the supplement on a regular basis enabled the reduction of the severe anaemia prevalence in most infants in this situation. However, this was not enough to change the situation of moderate anaemia. Taking in account the results here observed we can question about the effectiveness of such program.

The results of this study highlight, once again, the importance of nutrition not only as the main determinant of anaemia but also for the adequate development and growth especially among children in the first 2 years of life ${ }^{18-26}$. It was further found that the response to a martial supplement is much quicker and more efficient the higher the depletion level is.

Maintaining moderate prevalence of anaemia suggest a hypothesis of insufficient intervention time. The extension of this time, in turn, resulted along with the increase of rejection, as already mentioned - the tripling of the cost of the intervention. Increasing the frequency of ingestion to 2 or 3 times per week, in turn, increase the risk of deleterious effects described for the ferrous sulphate. It cannot be missed that for infants,

\section{REFERENCES}

1. International Nutritional Anaemia Consultative Group (INACG) Guidelines for the eradication of iron deficiency anaemia. New York, NY \& Washington, DC: Nutrition Foundation, 1977 https://www.google.com.br/?gfe_rd= ncr\&ei=EoRaU9naI6Wj8we18oDgAg\#q=I nternational + Nutritional + Anaemia + Consultative+Group, +1977+DOI\&spell $=1$

2. Liu X-N, Kang J, Zhao L, Viteri FE. Intermittent iron supplementation in Chinese pre-school children is efficient and safe. FoodNutr Bull 1995; 16: 139-46. www.popline.org/node/ 300384

3. BRASIL Ato Portaria No $730 / \mathrm{GM}$ em 13 de maio de 2005. Áreas de atuação. Alimentos. Legislação especifica da área por assunto. Programa Nacional de Suplementação de Ferro destinado a prevenir a anaemia ferropriva, institutionalized or not, milk is the main meal and itis an inhibitor for the iron absorption ${ }^{29}$.

Certainly, the results of this study emphasize the need of creating new strategies to combat anaemia. Possibly the technique of community fortification along with the use of an iron supplement with high potential for intake responds more effectivelyto the commitment of the parents to control anaemia due to iron deficiency ${ }^{27}$.

As has been highlighted ${ }^{30}$, there are stillmanygaps, responses to which can lead to controlling nutritional anaemia, despite its epidemiological and clinical impact, there are still uncertainties regarding its causes, epidemiology, diagnosis and treatment.

As described in the Social Development National Research ${ }^{28}$ the high prevalence of anaemia among women two years after that the program of corn flour and wheat flour fortification was implemented in Brazil,together with the high anaemia prevalence among children who had access to the iron supplementation program during their lactation period, remarks the need of wider and further discussions to look for new options and strategies to reach better results in shorter term than today in order to control this malnutrition.

In conclusion, the PNSF showed an increase in the concentration of haemoglobin among children with severe anaemia, but didn't show the same efficacy among children with moderate anaemia. Thus, there is not a clear perspective about the effectiveness of the implementation of PNSF as a solution to control the deficiency of iron in infants.

\section{ACKNOWLEDGMENTS}

To the National Council of Scientific and Technology Development (CNPq). Brazil.

To the Health Secretary Office of Guaruja, SP,

To the Post Graduate Public Health Program of Public Health School of University of Sao Paulo, Brazil.

http//www.saude.gov.br/nutricao/documentos/ portaria_730_ferro.pdf]

4. Monteiro CA, Szarfarc SC, et al Long-term preventive mass prescription of weekly doses of iron sulphate may be highly effective. Food and Nutrition Bulletin, 22(1):53-60, 2001. https://www.google.com.br/?gfe_rd= cr\&ei $=$ toVaU6PtIKKj 8 websIFw \# q = Food+and+Nutrition+Bulletin $\% 2 C+22(1) \%$ 3 A53-60\%2C+2001.

5. Brasil. Ministério da Saúde. Secretaria de Políticas de Saúde. Projeto para o controle da anaemiaferropriva em crianças menores de 2 anos nos municípios do Projeto de Redução da Mortalidade na Infância. Brasília: Ministério da Saúde, 1998. 6p.

6. WORLD HEALTH ORGANIZATION (WHO). Iron deficiency anaemia: assessment, prevention and control. A guide for programme 
managers.Geneva, 2001 programme+ managers.+Geneva\%2C+2001

7. Monteiro CA, Szarfarc SC. Estudo das condições de saúde das crianças no Municipio de Sâo paulo, SP,(Brasil), 1984-1985. V. Anaemia. Revista de Saúde Pública (SP) 1987, v.21,?gfe_rd=cr\&ei=toZaU7zGG6yj8wfW3oG4Ag

8. Horton S, Ross J. The economics of iron deficiency.Food Policy. 2003:28(1): 51-75. www.idpas.org/.../2206TheEconomics ofIronDeficie

9. Granthan-MacGregor S. A review of studies on the effect of iron deficiency on cognitive development in children.J.Nut.2001. www. revistas.usp.br/jhgd/article/viewFile/ 20025/22111ý

10. Szarfarc SC, Berg G, Santos ALS, Souza SB, Monteiro CAO controle da anaemia na infância atraves da rede báseica de saúde. J. Pediatria (RJ)72:329-34, 1996 https:/www.google. com.br/?gfe_rd=cr\&ei=toZaU7zGG6y j8wfW3oG4

11. de Souza OF, et al. Prevalence and associated factors to anaemia in children .J. Hum. Growth Dev. 2012; 22(3): 307-313

12. Assis AMO, Gaudenzi EN, Gomes G, Ribeiro RC, Szarfarc SC, Souza SB. Níveis de hemoglobina, aleitamento materno e regime alimentar no primeiro ano de vida. Rev. Saúde Pública. 2004:38(4):543-51.http://www.scielo.br/pdf/ rsp/v38n4/21084.pdf

13. Szarfarcet al A concentração de hemoglobina no primeiro ano de vida da clientela de serviços públicos de saúde do Brasil. Cad. Saúde Pública, Rio de Janeiro, 2004;20(1):266-74. www.scielo.br/scielo.php?script $=$ sci_ arttext...84842010000800002ý

14. Frota MTBA. Prevalência e fatores associados à anaemia em mulheres e crianças no Maranhão. [Tese Doutorado]. Fac. Saúde Pública da USP, 2013..www.teses.usp.br/teses/ disponiveis/6/6138/..08042013.../ TerezaFrota.pdf.

15. Almeida CA, Ricco RG, Ciampo LA, Souza AM, Pinho AP, Oliveira JE. Factors associated with iron deficiency anaemia in Brazilian preschool children. J Pediatr (Rio J). 2004 May-Jun; 80(3): 229-34.

16. Torres MAA et al. Anaemia em crianças menores de dois anos atendidas nas unidades básicas de saúde no Estado de São Paulo, Brasil. Revista de Saúde Pública, São Paulo, 1994; 28: 290-4. www.scielo.br/scielo.php?pid=S003489102001000100010\&script...

17. Monteiro CA, Mondini, L e Szarfarc, SCTendência secular da anaemia na infância na cidade de São Paulo (1984-1996). Revista de Saúde Pública, São Paulo, v. 34, n.6, p. 62-72, 2000. www.scielo.br/scielo.php?script $=$ sci_arttext... 89102000000700003

18. Torres, MAA. Programa de fortificação do leite pasteurizado e de atividades de educação em saúde e nutrição, na prevenção e recuperação da anaemiacarencialferropriva, em crianças menores de dois anos. São Paulo, 2000. Tese de Doutorado. Centro de Referência da Saúde da Mulher e de Nutrição, Alimentação e Desenvolvimento Infantil - Secretaria da Saúde do Estado de São Paulo. www.scielo.br/ scielo.php?script=sci_arttext\&pid=S1516...

19. Alleo LG, Souza SB, Szarfarc SC. Feeding practices in the first year of life, Journal of Human Growth and Development, 24(2): 195200. www.revistas.usp.br/jhgd/article/viewFile /81222/86109

20. Augusto RA, Souza JMP. Crescimento de crianças em aleitamento materno exclusivo no primeiro semestre de vida. RevBras Crescimento Desenvolv Hum 2007; 17(2): 01-11 www.revistas.usp.br/jhgd/article/ download/19827/21899.

21. Parada CMGL, Carvalhaes MABL, Jamas MT. Práticas de alimentação complementar em crianças no primeiro ano de vida. Rev Latinoam Enfermagem 2007 março-abril; 15(2). http://www.scielo.br/pdf/rlae/v15n2/ pt_v15n2a14.pdf.

22. Bernardi JLD, Jordão RE, Filho AAB. Alimentação complementar de lactentes em uma cidade desenvolvida no contexto de um país em desenvolvimento. Rev Panam Salud Publica 26(5), 2009. http://www.scielosp.org/pdf/ rpsp/v26n5/04.pdf

23. Torigoe CY, Asakura L, Sachs A, Silva CVD, Abrão ACFV, Santos GMS, Coelho LC. Influência da orientação nutricional nas práticas de alimentação complementar em lactentes. J.Human Growth and Development 2012;22: 1-11. www.revistas.usp.br/jhgd/article/ download/20055/22169

24. Vieira GO, Silva LR, Vieira TO, Almeida JAG, Cabral VA. Hábitos alimentares de crianças menores de 1 ano amamentadas e não amamentadas. J Pediatr (RJ). 2004;80(5):4116. http://www.scielo.br/pdf/jped/v.80n5/ v80n5a13.pdf

25. Simon VGN, Souza JMP, Souza SB. Introdução de alimentos complementares e sua relação com variáveis demográficas e socioeconômicas, em crianças no primeiro ano de vida, nascidas em Hospital Universitário no município de São Paulo. Rev. Bras. Epidemiol. Vol.6, №1, 2003. http://www.scielosp.org/pdf/rbepid/v6n1/ 05.pdf

26. Assis AMO, Gaudenzi EN, Gomes G, Ribeiro RC, Szarfarc SC, Souza SB. Níveis de hemoglobina, aleitamento materno e regime alimentar no primeiro ano de vida. Rev. Saúde Pública. 2004:38(4):543-51. http://www.scielo.br/pdf/ $\mathrm{rsp} / \mathrm{v} 38 \mathrm{n} 4 / 21084 . \mathrm{pdf}$

27. LINCH, SR The impact $f$ iron fortification on nutritional anaemia. Best Practica\& Research Clinical Haematology v.18, n.2.p.333-46, 2005) https://www.google.com.br/?gfe_rd =cr\&ei=toZaU7zGG6yj8wfW3oG4Ag \#q $=.+\mathrm{LINCH} \% 2 \mathrm{C}+\mathrm{SR}$

28. Brasil. Ministério da Saúde. Centro Brasileiro de Análise e Planejamento. Pesquisa Nacional de Demografia e Saúde da Criança e da Mulher. PNDS, 2006. Brasília. DF, 2009 www:// bvsms.saude.gov.br/bvs/publicações/ pnds.crianca mulher.pdf 
29. Levy-Costa RB, Monteiro CA. Consumo de leite de vaca e anaemia na infância no Município de São Paulo. Revista de Saúde Pública, 2004: 38,797-803. www.scielo.br/scielo.php? pid $=0034-891020040003 \&$ script $=s c i$
30. Batista Filho M, Souza AI, Bresani CC Anaemia como problema de saúde pública. Ciência e Saúde Coletiva, 2008; 13(6). www.redalyc.org/ pdf/630/63013624.pdf

\section{RESUMO}

Introdução: a deficiência de ferro ocorre em proporção endêmica entre a população infantil e constitui um dos fatores causais do inadequado desenvolvimento cognitivo, social, motor e de redução da capacidade de aprendizado, colocando os lactentes como grupo prioritário para programas de intervenção nutricional visando o controle da deficiência de ferro. Assim, em 2005 o Ministério da Saúde implantou o Programa Nacional de Suplemento de Ferro (PNSF) disponível para o universo de crianças de 6-24 meses atendidas em Unidades Básicas de Saúde. Objetivo: verificar a prevalência de anemia e a eficácia da suplementação profilática com o sulfato ferroso fornecido pelo Programa Nacional de Suplementação de Ferro (PNSF) do Ministério da Saúde do Brasil. Método: trata-se de estudo prospectivo de intervenção, que foi desenvolvido no município de Guarujá-SP no universo de crianças de 6-24 meses frequentadoras de creches públicas cujos responsáveis autorizaram sua participação. O suplemento de ferro foi oferecido de acordo com as normas do PNSF e o diagnóstico de anemia foi realizado antes e seis meses após o período de intervenção. Como critério de anemia utilizou-se os padrões da Organização Mundial da Saúde que define anemia moderada para valores de hemoglobina $(\mathrm{Hb})$ entre 11,0 e $9,5 \mathrm{gHb} / \mathrm{dL}$ e anemia grave para valores inferiores a $9,5 \mathrm{gHb} / \mathrm{dL}$. Resultados: do total das 136 crianças menores de 2 anos, $81 \%$ participou do estudo. Não foi encontrada diferença estatisticamente significativa entre a concentração média de Hb antes e após o período de intervenção ( $p=0,684)$. A média inicial de $\mathrm{Hb}$ foi $11,6 \mathrm{~g} / \mathrm{dL}(\mathrm{D} . \mathrm{p} .=1,82)$ e a final $11,5 \mathrm{~g} / \mathrm{dL}$ (d.p.1,31). Embora apenas 11 dos 49 anêmicos atingissem os valores normais, 33 deles apresentaram um aumento na concentração de $\mathrm{Hb}$. Conclusão: houve um aumento na concentração de hemoglobina entre as crianças com anemia grave. Não houve mudança na situação das crianças com anemia moderada. A suplementação com sulfato ferroso não foi suficientemente eficiente no controle da deficiência de ferro de lactentes na população assistenciada.

Palavras-chave: anemia, anemia ferropriva, lactentes, suplementação com ferro, sulfato ferroso, programa nacional de suplemento de ferro (PNSF). 